\title{
Using full-scale duckweed ponds as the finish stage for swine waste treatment with a focus on organic matter degradation
}

\author{
R. A. Mohedano, R. H. R. Costa, S. M. Hofmann and P. Belli Filho
}

\begin{abstract}
The rapid increase in the number of swine has caused pronounced environmental impacts worldwide, especially on water resources. As an aggregate, smallholdings have an important role in South American pork production, contributing to the net diffusion of pollution. Thus, duckweed ponds have been successfully used for swine waste polishing, mainly for nutrient removal. Few studies have been carried out to assess organic matter degradation in duckweed ponds. Hence, the present study evaluated the efficiency of two full-scale duckweed ponds for organic matter reduction of swine waste on small pig farms. Duckweed ponds, in series, received the effluent after an anaerobic biodigester and storage pond, with a flow rate of $1 \mathrm{~m}^{3}$ day ${ }^{-1}$. After 1 year of monitoring, an improvement in effluent quality was observed, with a reduction in biochemical oxygen demand (BOD) and total chemical oxygen demand (tCOD), respectively, of 94.8 and $96.7 \%$, operating at a loading rate of approximately $27 \mathrm{kgBOD} \mathrm{ha}{ }^{-1} \mathrm{day}^{-1}$ and $131 \mathrm{kgCOD} \mathrm{ha}^{-1} \mathrm{day}^{-1}$. Algae inhibition due to duckweed coverage was strongly observed in the pond effluent, where chlorophyll $a$ and turbidity remained below $25 \mu \mathrm{g} \mathrm{L}^{-1}$ and $10 \mathrm{NTU}$. Using the study conditions described herein, duckweed ponds were shown to be a suitable technology for swine waste treatment, contributing to the environmental sustainability of rural areas.
\end{abstract}

Key words | duckweed, organic matter, stabilisation ponds, swine waste, treatment

\section{INTRODUCTION}

Currently, pig farming is the main source of animal protein for human nutrition, and it occupies a strategic position in global food production (FAO 2009). However, the fast growth of this industry has resulted in major environmental impacts, especially in developing countries, such as Brazil (the third largest producer of pork worldwide). The high load of organic matter and nutrients found in pig manure have caused ecological imbalances when released to waterways, such as the eutrophication of major river basins in pork producing regions. Moreover, much of the pig production in developing countries occurs on small farms, which have inadequate financial resources to build waste treatment systems and therefore release swine operation emission that contributes to the non-point source pollution of receiving waterways.

With the intent of controlling pollution, many producers have installed anaerobic biodigesters (BDs) for pig manure treatment and valorisation. In addition to having low

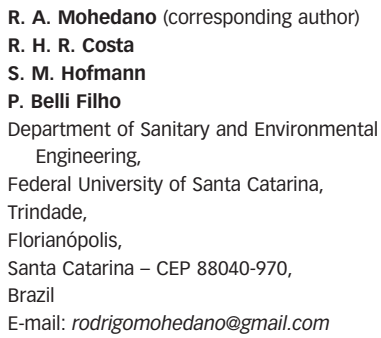

installation and operation costs, this technology produces biogas, a value-added by-product that can be used as fuel for energy generation. However, the effluent from BDs generally requires a polishing step before it can be released into a water body because of the high concentrations of nutrients, pathogens and organic matter. Thus, as an alternative to BD effluent polishing, duckweed ponds have arisen as an efficient and low-cost option (Bergmann et al. 20ooa; Cheng et al. 2002a, 2002b; Xu \& Shen 20II; Mohedano et al. 20I2a).

The group of small aquatic plants commonly referred to as duckweed has been successfully used in effluent treatment systems, mainly for agricultural and municipal wastewater (Cheng et al. 2002a; Mohedano et al. 2012b). For several decades, duckweed ponds have been investigated and used because of their high capacity for nutrient recovery, which includes mainly nitrogen compounds as well as phosphates and heavy metals. In addition to nutrient up-take, the dissolved oxygen increase in the water column 
due to duckweed photosynthetic activity and the increased surface area for attachment (on the roots) promote aerobic microorganism growth, improving nitrification and organic matter oxidation. On the other hand, duckweed grows at a higher rate than vascular plants; thus, in treatment ponds, this biomass produced should be removed regularly for efficient wastewater treatment. However, the advantage of this plant group over other macrophytes used in effluent treatment, such as water hyacinth (Eichhornia spp.), is the production of biomass with high nutritional value, reaching crude protein (CP) levels of more than 40\% (Landesman et al. 2002). The high CP levels in duckweed make this plant an ideal animal feed additive that may generate cost savings in swine production by minimising the cost of animal rations. Additionally, recent research provides evidence for the potential of duckweed biomass to be used as a bioethanol production system (Cheng \& Stomp 2009; Xu et al. 20II).

This plant group taxonomy has undergone some changes in recent years. Duckweed belonged to the Lemnaceae family but is currently classified as a member of the subfamily Lemnoideae within the family Araceae, with approximately 40 species in five genera (APG II 2003). Among the species of duckweed, not all are effective for the treatment of agricultural effluents and for protein production for animal feed. Bergmann et al. (200ob) assessed 41 geographically isolated duckweeds to determine the species that have the greatest potential for the treatment of swine waste and for protein production, and found that the variety Landoltia punctata (used in the present study) was best for protein production.

Most studies regarding swine waste treatment using duckweed ponds have focused on nutrient removal, but organic matter reduction data are scarce (Bergmann et al. 2000a; Cheng et al. 2002a, b; Mohedano et al. 2012a, b). Thus, the present study aimed to evaluate the performance of full-scale duckweed ponds used for the post-treatment of swine waste, with a focus on organic matter degradation.

\section{$\overline{\text { MATERIAL AND METHODS }}$}

\section{Swine waste treatment system description}

The experiment was conducted at a small pig farm (approximately 300 animals) located in the municipality of Braço do Norte, Santa Catarina State, southern Brazil (28 13'50.1" S and $49^{\circ} 06^{\prime} 29.2^{\prime \prime} \mathrm{W}$ ) in a sub-temperate climate. This region has one of the largest swine densities worldwide, which causes serious environmental problems.

The swine waste, composed mainly of manure, urine and leftover food, was processed through a treatment system composed of an anaerobic $\mathrm{BD}$, a storage pond (SP), and two duckweed ponds, named DP1 and DP2. The characteristics of each stage are described in Table 1.

Anaerobic treatment systems, traditionally composed of BDs and SPs, are commonly used on pig farms in Brazilian swine production regions. Beyond the low cost of treatment and any generated revenue from biogas generation, this stage is important for waste stabilisation and storage for later use as a fertiliser. According to Brazilian law (Santa Catarina State), pig manure must be stored for at least 120 days to reduce the pollutant potential before land application, the rate of which should not exceed $50 \mathrm{~m}^{3} \mathrm{ha}^{-1}$ year $^{-1}$. However, many farms often generate a surplus of waste, which necessitates a polishing step prior to the effluent being released to the environment. Thus, a duckweed pond system is evaluated here for this purpose.

Duckweed ponds were excavated with a pond wall slope of $45^{\circ}$ and lined with a high-density polyethylene geomembrane. DP1 and DP2 were connected in series. Finally, the treated effluent was stored in a 5,000 L reservoir that was reused for pigsty cleaning. The entire treatment system is shown in Figure 1.

Initially, the duckweed ponds were filled with rain water and river water and then received low-concentration loads of swine waste that had been pretreated by the BDG (approximately $1 \%$ swine waste). For the adaptation period, duckweed plants (Landoltia punctata) were collected from a natural eutrophic water body located nearby and introduced into the duckweed ponds to cover the water surface at a density of approximately $220 \mathrm{~g} \mathrm{~m}^{-2}$ (fresh weight). The species $L$. punctata was chosen because, in addition to

Table 1 | Characteristics of the treatment units

\begin{tabular}{lcrrr} 
Dimensions & BD & \multicolumn{1}{l}{ SP } & DP1 & DP2 \\
\hline Length $(\mathrm{m})$ & 6.0 (diameter) & 22.0 & 21.0 & 15.0 \\
Width $(\mathrm{m})$ & 6.0 (diameter) & 8.0 & 7.0 & 6.0 \\
Depth $(\mathrm{m})$ & 4.0 & 3.0 & 0.8 & 0,4 \\
Area $\left(\mathrm{m}^{2}\right)$ & 28.3 & 176.0 & 153.0 & 90.0 \\
Useful volume $\left(\mathrm{m}^{3}\right)$ & 90.0 & 360.0 & 101.0 & 33.0 \\
Flow rate $\left(\mathrm{m}^{3} \mathrm{day}^{-1}\right)$ & 3.0 & 3.0 & 1.0 & 1.0 \\
HRT (day) & 30.0 & 120.0 & 101.0 & 33.0 \\
\hline
\end{tabular}

$\mathrm{BD}=$ biodigester; $\mathrm{SP}=$ storage pond $\mathrm{DP} 1=$ duckweed pond $1 ; \mathrm{DP} 2=$ duckweed pond 2 ; $\mathrm{HRT}=$ hydraulic retention time 


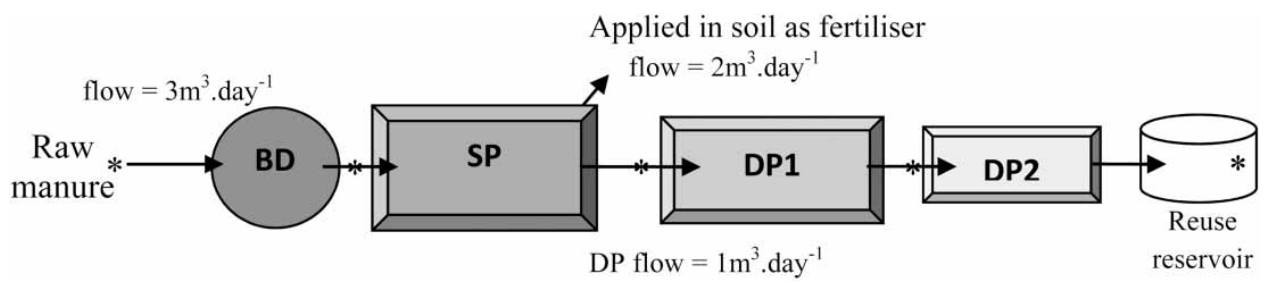

Figure 1 | Treatment system design: BD - biodigester; SP - storage pond; DP1 - duckweed pond 1; DP2 - duckweed pond 2. * Points of sampling

being a native species of southern Brazil, it has been recommended by many previous studies for this purpose (Bergmann et al. 200ob; Cheng et al. 2002a; Chaiprapat et al. 2005). According to Cheng et al. (2002a), this duckweed species can support high loads of ammonia and can produce a high-protein biomass, which makes it adequate for swine waste treatment. Additionally, bamboo dividers were floated across the pond to minimise the wind drag.

\section{Operation and monitoring}

Accounting for the usual cleaning of pigsties and the seasonal variations in the livestock population at pig farms, the effluent was pumped into the BD every 3 days, on average, at a volume of $9 \mathrm{~m}^{3}$. This flow rate, approximately $3 \mathrm{~m}^{3} \mathrm{day}^{-1}$, provides a 30 day hydraulic retention time (HRT), assuming the useful volume of a BD is $90 \mathrm{~m}^{3}$. After leaving the anaerobic digester, the effluent is drained to a SP, from which $2 \mathrm{~m}^{3}$ day $^{-1}$ (on average) were land applied for agricultural fertilisation. The remainder, approximately $1 \mathrm{~m}^{3} \mathrm{day}^{-1}$, was transferred to DP1 to start the polishing process. The effluent load sent to the duckweed ponds, which were in series, was in batch loads of $15 \mathrm{~m}^{3}$ every 15 days, so the BD effluent flow rate applied to DP1 and DP2 was $1 \mathrm{~m}^{3} \mathrm{~d}^{-1}$, on average.

The effluent quality was monitored over a 1 year period. Liquid samples were collected every 2 weeks at points of entry and exit of each stage of the system. After collection, the samples were forwarded to the analytical laboratory at the Environmental Engineering Department of the Federal University of Santa Catarina. The parameters analysed were $\mathrm{pH}$, temperature, turbidity and DO (dissolved oxygen), which were measured using an electronic probe (in situ), and total chemical oxygen demand (tCOD), biochemical oxygen demand $\left(\mathrm{BOD}_{5}\right)$, chlorophyll $a$ and total solids (TS) were analysed at the laboratory according to Standard Methods (APHA 2005). All analyses were conducted on raw (unfiltered) samples because the solid portion of swine waste is important to consider. To determine the mean values, standard deviation and significant differences, statistical inference (analysis of variance) was used to evaluate the results using the Statistica 7.0 software by Statsoft.

The removal of excess biomass is an important aspect of operating duckweed ponds and is a key factor for the successful polishing of swine waste after anaerobic BD treatment. Thus, fresh duckweed biomass was removed at average rates of approximately 50 and $22 \mathrm{~kg}$ every 2 days from DP1 and DP2, respectively. This amount of biomass removal was enough to maintain a duckweed biomass surface density of approximately $600 \mathrm{~g} \mathrm{~m}^{-2}$ during the operation of the duckweed ponds.

\section{RESULTS AND DISCUSSION}

\section{Considerations of the anaerobic pretreatment stage}

Throughout the experimental period, approximately $1,140 \mathrm{~m}^{3}$ of swine waste was treated by the treatment system. Considering the full-scale operation, the observed conditions during the monitoring period were influenced by the high variability of the composition of the raw manure, which was confirmed by a high standard deviation among the operational parameters, as shown in Table 2.

The anaerobic pretreatment played a crucial role in organic matter removal, making the effluent suitable for duckweed pond use as a polishing step. Additionally, ammonia reduction during pretreatment was an important factor, taking into account the toxicity of this substance to duckweed species (Mohedano et al. 20I2a, b), which decreased from 1,624 to $636 \mathrm{mgNH}_{3} \mathrm{~L}^{-1}$ prior to inflowing to DP1. Anaerobic pretreatments often achieve a high COD and BOD removal efficiency when used for pig manure treatment, mainly due to the high initial concentration and high biodegradability of pig manure. The COD/BOD ratio increased from 1.1 in raw manure to 5.8 in $\mathrm{BD}$ effluent, demonstrating a strong consumption of organic matter by available anaerobic microorganisms (Table 2). For this reason, pig waste has been successfully used for methane production in BDs and as an energy source worldwide. 
Table 2 | Characteristics of effluent after anaerobic pretreatment only

\begin{tabular}{llll} 
& Raw manure & Biodigestor & Storage pond \\
\hline $\mathrm{pH}$ & $7.52 \pm 0.6$ & $7.19 \pm 0.7$ & $7.38 \pm 0.4$ \\
$\mathrm{DO}\left(\mathrm{mg} \mathrm{L}^{-1}\right)$ & 0.0 & 0.0 & $0.2 \pm 0.19$ \\
Temperature $\left({ }^{\circ} \mathrm{C}\right)$ & $19.7 \pm 2.9$ & $19.9 \pm 3.3$ & $20.1 \pm 4.2$ \\
Turbidity (NTU) & - & $4.136 \pm 3.510$ & $788 \pm 661$ \\
TS $\left(\mathrm{mg} \mathrm{L}^{-1}\right)$ & $268.350 \pm 185.757$ & $10.303 \pm 7.825$ & $5.052 \pm 4.024$ \\
tCOD $\left(\mathrm{mg} \mathrm{L}^{-1}\right)$ & $63.280 \pm 23.065$ & $8.758 \pm 7.173$ & $3.107 \pm 2.411$ \\
BOD $_{5}\left(\mathrm{mg} \mathrm{L}^{-1}\right)$ & $57.533 \pm 29.178$ & $1.492 \pm 1.445$ & $653 \pm 352$ \\
Escherichia coli $\left(\mathrm{MPN} .100 \mathrm{~mL}^{-1}\right)$ & $2.4 \times 10^{7}$ & $3.5 \times 10^{5}$ & $6.8 \times 10^{4}$ \\
\hline
\end{tabular}

Despite the high removal efficiency, the effluent of the anaerobic stage still requires a polishing step to meet the environmental standards for the effluent from duckweed ponds.

\section{Performance of duckweed ponds}

As an important result, it was observed that duckweed ponds promoted a significant increase in the DO concentration in the ponds. In the effluent from the SP (DP1 influent) the DO concentration was lower than $0.2 \mathrm{mg} \mathrm{L}^{-1}$; however, in the duckweed ponds, the surface DO concentrations reached $2.0 \pm 1.4$ and $3.0 \pm 1.2 \mathrm{mg} \mathrm{L}^{-1}$ for DP1 and DP2, respectively (Table 3). Similarly, Alaerts et al. (I996) observed a DO range between 2 and $4 \mathrm{mg} \mathrm{L}^{-1}$ in duckweed ponds that were used for domestic sewage treatment. El-Shafai et al. (2007) also observed an increase in DO through three duckweed ponds in series, from approximately 0.5 to 3.5 to 6.0 .

However, there is not a consensus among authors. In some cases, the biomass coverage in duckweed ponds may obstruct the diffusion of atmospheric oxygen through the water column. Using domestic sewage, Nozaily et al. (2000) found that the role of duckweed was marginal in

Table 3 | Observed dissolved oxygen $\left(\mathrm{mg} \mathrm{L}^{-1}\right)$ in duckweed ponds

\begin{tabular}{lrrrrr} 
& $\begin{array}{l}\text { Influent } \\
(\mathbf{S P})\end{array}$ & $\begin{array}{l}\text { DP1 } \\
\text { surface }\end{array}$ & $\begin{array}{l}\text { DP1 } \\
\text { bottom }\end{array}$ & $\begin{array}{l}\text { DP2 } \\
\text { surface }\end{array}$ & \multicolumn{1}{c}{$\begin{array}{l}\text { DP2 } \\
\text { bottom }\end{array}$} \\
\hline Average & 0.20 & 2.01 & 0.72 & 3.02 & 1.43 \\
$\begin{array}{l}\text { Stand. } \\
\text { deviation }\end{array}$ & \pm 0.19 & \pm 1.36 & \pm 0.57 & \pm 1.20 & \pm 1.15 \\
$\begin{array}{l}\text { Maximum } \\
\text { Minimum }\end{array}$ & 0.60 & 6.50 & 2.00 & 5.30 & 3.50 \\
\hline
\end{tabular}

$\mathrm{DP} 1=$ duckweed pond $1 ; \mathrm{DP} 2=$ duckweed pond 2; SP = storage pond removing COD from wastewater, although this was mainly observed in deeper ponds. These authors also affirmed the idea that filtered COD removal was largely determined by volume-related microbial processes and not by surfacerelated duckweed uptake or oxygen fluxes between the atmosphere and pond surface.

By contrast, Körner et al. (I998) studied the organic material degradation in duckweed systems by comparing 'synthetic plastic duckweeds' and real duckweed populations. They concluded that the degradation of organic material was enhanced by living duckweed through both the additional oxygen supply from photosynthetic activities and the additional surface area for microorganism growth. Apparently, duckweed cannot be replaced easily by artificial surfaces for bacterial growth and/or artificial oxygen supply by pumps. Possible explanations include: (i) a difference in the attached bacterial community, where bacteria on duckweed would apparently be more effective for the degradation of organic matter; or (ii) a difference in the way oxygen is diffused into the water by duckweed roots and lower fronds, providing oxygen diffusion at a 'microsite level' within the biofilm (Körner et al. 2003). Korner et al. (I998) also suggested that the oxygen incorporation rate to the liquid by duckweeds can reach approximately $1 \mathrm{mgO}_{2} \mathrm{~L}^{-1} \mathrm{~h}^{-1}$.

Indeed, the mechanisms for oxygen transfer into the water column provided by the duckweed mat are not clear in the literature. Most duckweed species, such as Landoltia punctata, have stomata facing upwards that release oxygen into atmosphere, which does not help to explain the increased DO content in the water column. As a hypothesis, the thin cell wall, low lignin content and chloroplasts present in duckweed roots allow for oxygen flow from plant tissues to water by direct diffusion. Thus, the attached heterotrophic community may benefit by using DO, enhancing the oxidation of organic matter in the pond. 


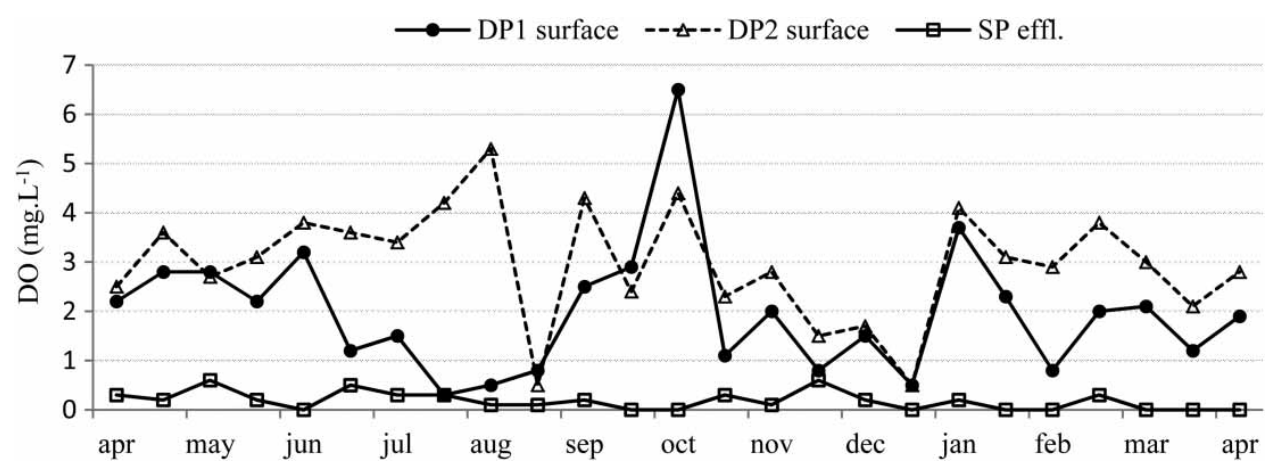

Figure 2 | Dissolved oxygen concentration during the monitored period (DP1 and DP 2 = duckweed pond 1 and 2; SP = storage pond).

Figure 2 presents the DO over the duration of the experiment (1 year), which showed high variation, although the DO concentration remained high for most of the study period, likely resulting in a stable aerobic environment inside the duckweed ponds.

Due to the increased availability of oxygen for aerobic microorganisms, a high efficiency for organic matter reduction was observed in the effluent from the duckweed ponds, in series. The organic matter reduction efficiency reached 96.7 and $94.8 \%$ for tCOD and $\mathrm{BOD}_{5}$, respectively, operating at a loading rate of approximately $131 \mathrm{kgCOD}$ ha day ${ }^{-1}$ and $27.5 \mathrm{kgBOD}_{5}$ ha day $^{-1}$. In Table 4 , the applied and removed organic loading rates are shown for each pond. Considering the whole duckweed pond stage, DP1 played a major role in waste treatment, driving most of the load reduction (Figure 3). This fact is elucidated by the influent concentration, which was higher in the DP1 influent, and also due to the higher water volume and depth in DP1 $\left(\mathrm{DP} 1=101 \mathrm{~m}^{3}\right.$ and DP2 $\left.=33 \mathrm{~m}^{3}\right)$, which caused stability despite climate variations and an increasing HRT.

Araujo (2007) assessed stabilisation ponds for swine waste treatment at the same location and found a COD removal efficiency rate from 40 to $58 \%$ from an applied load of $112 \mathrm{~kg}$ $\mathrm{ha}^{-1} \mathrm{day}^{-1}$. To treat the same type of waste, Barthel (2007) evaluated water hyacinth ponds (Eichhornia sp.) at a high loading rate of approximately $245 \mathrm{~kg} \mathrm{ha}^{-1} \mathrm{day}^{-1}$ and

Table 4 | $\mathrm{BOD}_{5}$ and $\mathrm{COD}$ loading in duckweed ponds

\begin{tabular}{|c|c|c|c|c|c|c|}
\hline \multirow{2}{*}{$\begin{array}{l}\text { Duckweed } \\
\text { ponds }\end{array}$} & \multicolumn{2}{|c|}{$\begin{array}{l}\text { Application rate } \\
\left(\mathrm{kg} \mathrm{ha}^{-1} \mathrm{day}^{-1}\right)\end{array}$} & \multicolumn{2}{|c|}{$\begin{array}{l}\text { Removal rate } \\
\left(\mathbf{k g ~ h a}^{-1} \text { day }^{-1}\right)\end{array}$} & \multicolumn{2}{|c|}{ Efficiency (\%) } \\
\hline & BOD $_{5}$ & tCOD & BOD $_{5}$ & tCOD & $\mathrm{BOD}_{5}$ & tCOD \\
\hline DP1 & 44.4 & 203.1 & 36.9 & 190.8 & 86.8 & 91.7 \\
\hline DP2 & 6.5 & 14.9 & 4.2 & 7.9 & 64.6 & 56.7 \\
\hline
\end{tabular}

DP1 and DP2 = duckweed ponds 1 and 2. achieved a 33\% tCOD removal rate. Comparing these values to the duckweed pond experiments highlighted the benefits and increased efficiencies of the duckweed pond system.

In addition to the oxygen rise, the high tCOD removal efficiency may be due to the long HRT of approximately 134 days for DP1 and DP2 in series, the high influent concentration and the suitable temperature $\left(24^{\circ} \mathrm{C}\right.$ on average). Additionally, the ultraviolet shelter provided by duckweed coverage and the increased surface area for attachment promote heterotrophic microorganism growth, which may account for the increased organic matter consumption rate. Considering the consumption of macronutrients, such as nitrogen and phosphorus, there was a high removal rate by the duckweed ponds, for which direct uptake by plants plays an important role. These data were previously reported by Mohedano et al. (2012b).

As shown in Figure 4, DP2 presented a high range for tCOD and BOD values, most likely due to the lower water volume and lower HRT, which makes this second pond more susceptible to environmental changes, such as temperature and rain, as well as load variations. In the following charts (Figure 4), it can be observed that the tCOD removal efficiency dropped in June and December. This drop likely occurred due to strong winter winds (in June) that dragged duckweed coverage, allowing algae growth because of increased sunlight penetration. Except for this period of increased algae growth, where it reached $230 \mu \mathrm{g} \mathrm{L}^{-1}$, the chlorophyll a concentration remained below $25 \mu \mathrm{g} \mathrm{L}^{-1}$ (Figure 5). Through autotrophic metabolism, microalgae biomass fixes inorganic carbon and produces complex organic molecules (dead cells), causing an increase in organic matter in effluent samples.

Additionally, in December, a reduction in the duckweed population occurred, causing increased algae growth. This occurrence may be due to the expense of 

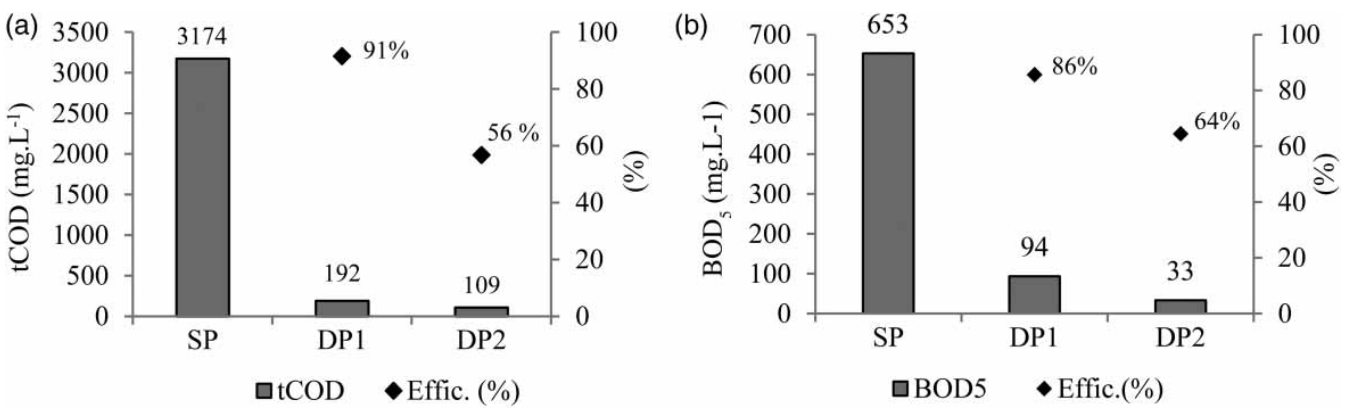

Figure 3 | Mean values for the $\mathrm{BOD}_{5}$ and tCOD concentration throughout the duckweed pond system and the average removal efficiency (SP = storage pond influent; DP1 and DP2 = duckweed pond 1 and 2).

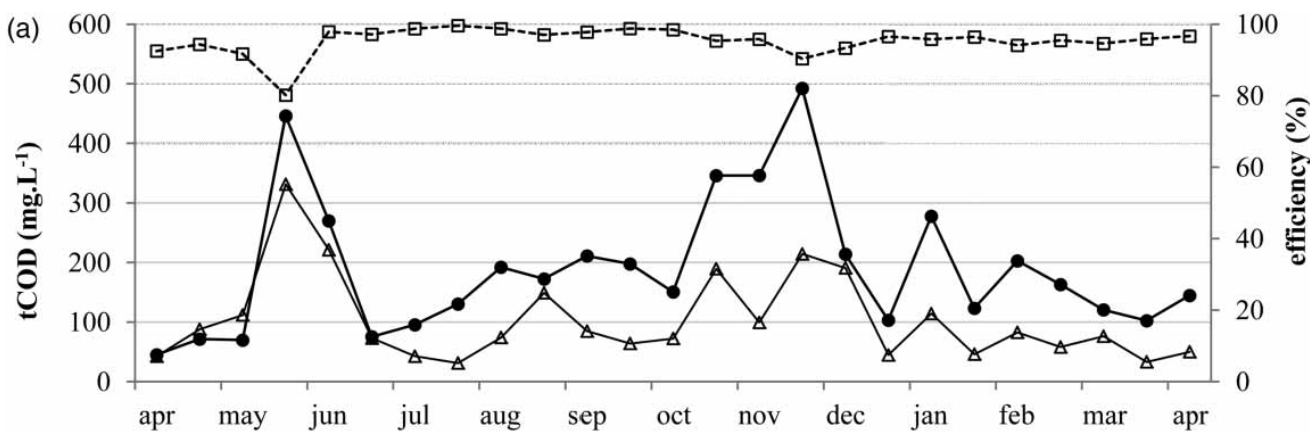

$\longrightarrow$ DP1 [tCOD] $\longrightarrow$ DP2 [tCOD] ---ษ--- total effic.

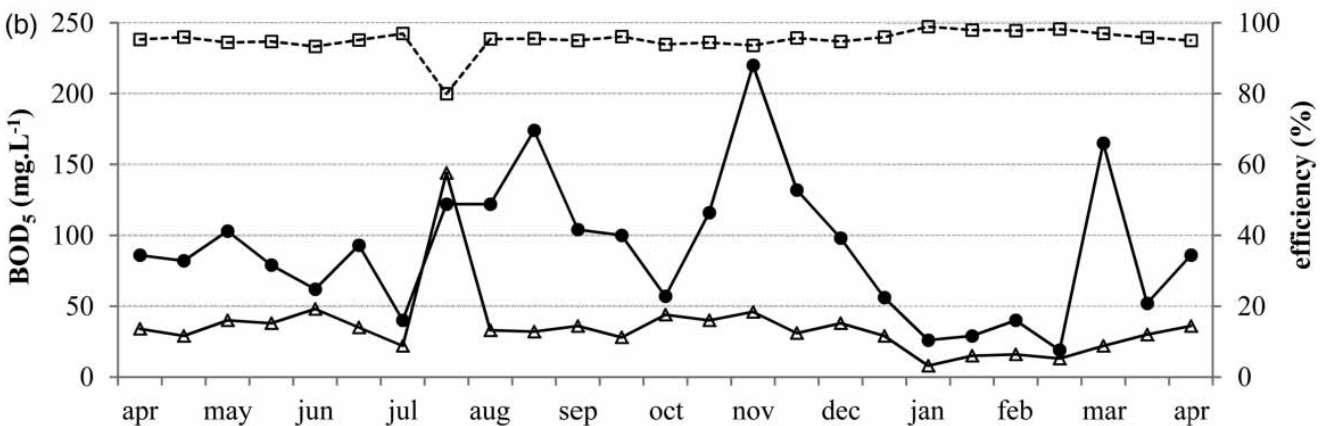

Figure $4 \mid$ tCOD (a) and $\mathrm{BOD}_{5}$ (b) concentration and total efficiency over the monitoring period (DP1 and DP $2=$ duckweed pond 1 and 2).

energy for flower production in spring. Thus, these events highlight the importance of cohesive duckweed coverage to the reduction of suspended solids due to algae inhibition and organic matter oxidation. According to many authors, algae growth is undesired in duckweed ponds used for wastewater treatment, mainly due to the competition for nutrients and resulting rise in $\mathrm{pH}$ that increases the ammonia toxicity (Iqbal 1999; Caicedo et al. 2000; Mohedano et al. 20I2a). The findings shown in Figure 2 reveal an unexpected trend in the data, wherein DO decreases at the same time that the algae population increases. This fact can be explained by considering the period of day when the measurement was made, that is, in the morning, at approximately 10:00 am. During the night, the DO is consumed by heterotrophic and autotrophic organisms, including algae. When the sun rises, the algal photosynthetic activity starts, producing DO in the water, which reaches a peak concentration at approximately 14:00 h.

TS decreased from $5,052 \mathrm{mg} \mathrm{L}^{-1}$ in the influent to $388 \mathrm{mg} \mathrm{L}^{-1}$ after DP2, representing a TS removal efficiency of $92.8 \%$. Additionally, $\mathrm{pH}$ values remained nearly neutral, becoming only slightly acidic over the full treatment system (7.52 to 6.68). This $\mathrm{pH}$ range is expected for swine 


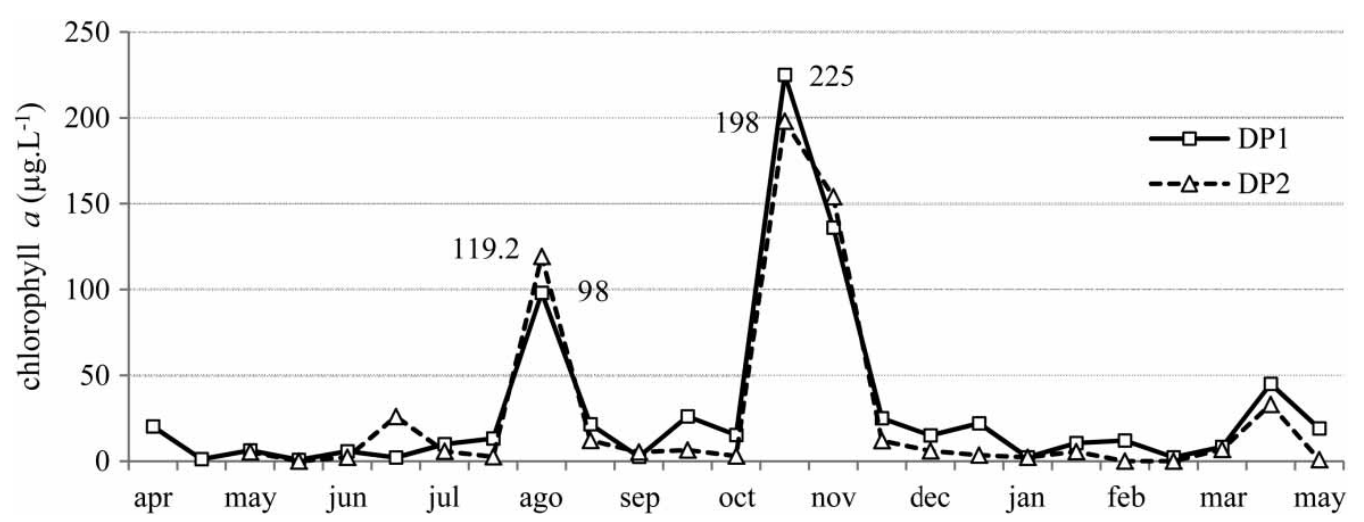

Figure 5 | Chlorophyll a concentration in duckweed ponds (DP1 and DP2) over the experimental period.

wastes; however, duckweed ponds usually have lower $\mathrm{pH}$ levels compared to maturation ponds due to algae inhibition and low $\mathrm{CO}_{2}$ consumption (Costa et al. 2009; Mohedano et al. 20I2a). According to Mohedano et al. (2012b), the nitrification process in duckweed ponds may slightly reduce the alkalinity and $\mathrm{pH}$ values.

A high HRT was also important for coliform reduction. In raw manure, the Escherichia coli cell concentration can exceed $2 \times 10^{7} \mathrm{MPN} 100 \mathrm{~mL}^{-1}$, and after the SP (at the duckweed pond inlet), this value decreased to $6.8 \times 10^{4}$ MPN $100 \mathrm{~mL}^{-1}$. There was also a $3 \log$ unit reduction in E. coli after the duckweed pond system; in other words, the samples collected at the DP2 outlet contained only 5.2.10 $0^{1} \mathrm{MPN} 100 \mathrm{~mL}^{-1}$ E. coli cell concentration. This value demonstrates that the final effluent is able to be reused for pigsty cleaning or irrigation, whilst abiding by Brazilian environmental discharge limits under the law. Indeed, the effluent reuse was carried out by farmers in this farm case study, resulting in a water economy of approximately $500 \mathrm{~m}^{3}$ over the experimental period (1 year).

\section{CONCLUSIONS}

Under the study conditions, duckweed ponds achieved a high efficiency for organic matter removal from swine waste, after anaerobic pretreatment, with an average percentage of approximately 96.7 and $94.8 \%$ for COD and $\mathrm{BOD}_{5}$, respectively. This fact may be due to the supply of DO by plant photosynthesis ( 2 to $3 \mathrm{mg} \mathrm{L}^{-1}$ on average), a long HRT (134 days) and a suitable average ambient temperatures. It was also possible to conclude that when duckweed coverage became unbundled, the algae growth resulted in a decrease in the removal efficiency for COD and $\mathrm{BOD}_{5}$, increasing suspended solids and chlorophyll $a$.
Additionally, the low concentration of E. coli and turbidity in final effluent allowed for the reuse of the treated final effluent for pigsty cleaning and irrigation, resulting in a water economy of approximately $500 \mathrm{~m}^{3}$. Moreover, duckweed is known to have a high protein biomass, which may be used for hog feed and represents a financial advantage. This technology is recommended for poor regions with high pork production because it will improve the environmental quality and sustainability of the region.

\section{$\overline{\text { ACKNOWLEDGEMENTS }}$}

The authors would like to thank the team from the Laboratory of Effluents at the Federal University of Santa Catarina, the Petrobrás Environmental Program (TSGA), FAPESC, CNPq and CAPES/PNPD. In addition, we are grateful to the Wiggers family for always cordially receiving us in their small-holding.

\section{REFERENCES}

Alaerts, G., Mahbubar, R. \& Kelderman, P. 1996 Performance analysis of a full-scale duckweed-covered sewage lagoon. Water Research 30 (4), 843-852.

APHA 2005 Standard Methods for the Examination of Water and Wastewater, 21st edn. American Public Health Association/ American Water Works Association/Water Environment Federation, Washington, DC, USA.

APG II (Angiosperm Phylogeny Group) 2003 An update of the Angiosperm Phylogeny Group classification for the orders and families of flowering plants: APG II. Botanical Journal of Linnean Society 141, 399-436, 20.

Araujo, I. S. 2007 Evaluation of full-scale facultative and maturation ponds on swine waste treatment. $\mathrm{PhD}$ thesis in Environmental Engineering. UFSC, Brazil. 
Barthel, L. 2007 High rate ponds, maturation and water hyacinth ponds using for pig manure treatment: planktonic dynamics evaluation and performance. Theses Environmental Engineering. Federal University of Santa Catarina (UFSC), Florianópolis, Brazil.

Bergmann, B. A., Cheng, J., Classen, J. \& Stomp, A. M. 200oa Nutrient removal from swine lagoon effluent by duckweed. Transactions of the ASAE 42 (2), 263-269.

Bergmann, B. A., Cheng, J., Classen, J. \& Stomp, A. M. 2ooob In vitro selection of duckweed geographical isolates for potential use in swine lagoon effluent renovation. Bioresource Technology 73 (1), 13-20.

Caicedo, J. R., Van Der Steen, N. P., Arce, O. \& Gijzen, H. J. 2000 Effect of total ammonia nitrogen concentration and $\mathrm{pH}$ on growth rates of duckweed (Spirodela polyrrhiza). Water Research 34 (15), 3829-3835.

Chaiprapat, S., Cheng, J. J., Classen, J. J. \& Liehr, S. K. 2005 Role of internal nutrient storage in duckweed growth for swine wastewater treatment. Transactions of the ASAE 48 (6), 2247-2258.

Cheng, J., Bergman, B. A., Classen, J. J., Stomp, A. M. \& Howard, J. W. 2002a Nutrient recovery from swine lagoon water by Spirodela punctata. Bioresource Technology 81, 81-85.

Cheng, J., Landesman, L., Bergman, B. A., Classen, J. J., Howard, J. W. \& Yamamoto, Y. T. 2002b Nutrient removal from swine lagoon liquid by Lemna minor. American Society Agriculture Engineering 45 (4), 1003-1010.

Cheng, J. J. \& Stomp, A. M. 2009 Growing duckweed to recover nutrients from wastewaters and for production of fuel ethanol and animal feed. Clean: Soil Air Water 37 (1), 17-26.

Costa, R. H. R., Araujo, I. S. \& Belli, P. B. 2009 Algae biomass evaluation in aerated facultative and maturation ponds for piggery waste treatment. 8th IWA Specialist Group Conference on Waste Stabilization Ponds. Ed. IWA \& ABRH, Belo Horizonte, Brazil.

FAO (Food and Agriculture Organization of the United Nations). 2009 The State of Food and Agriculture. http://www.fao.org/ docrep/012/i0680e/i0680e.pdf (accessed 20 April 2013).
Iqbal, S. I999 Duckweed aquaculture. Potentials, possibilities and limitations, for combined wastewater treatment and animal feed production in developing countries. Report No. 6/99, SANDEC/EAWAG Water \& Sanitation in Developing Countries, Duebendorf, Switzerland.

Körner, S., Lyatuu, G. B. \& Vermaat, J. E. 1998 The influence of Lemna gibba on the degradation of organic material in duckweed-covered domestic wastewater. Water Research 32 (10), 3092-3098.

Körner, S., Vermaat, J. E. \& Veenstra, S. 2003 The capacity of duckweed to treat wastewater: ecological considerations for a sound design. Journal of Environmental Quality 32, 1583-1590.

Landesman, L., Chang, J., Yamamoto, Y. \& Goodwin, J. 2002 Nutritional value of wastewater-grown duckweed for fish and shrimp feed. World Aquac. 33 (4), 39-40.

Mohedano, R. A., Costa, R. H. R., Tavares, F. A. \& Belli Filho, P. 20I2a High nutrient removal rate from swine wastes and protein biomass production by full-scale duckweed ponds. Bioresource Technology 112, 98-104.

Mohedano, R. A., Velho, V. F., Costa, R. H. R., Hofmann, S. M. \& Belli Filho, P. 20ı2b Nutrient recovery from swine waste and protein biomass production using duckweed ponds (Landoltia punctata): Southern Brazil. Water Science and Technology 65 (11), 2042-2048.

Nozaily, F., Alaerts, G. \& Veenstra, S. 2000 Performance of duckweed-covered sewage lagoon - oxygen balance and cod removal. Water Research 34 (10), 2727-2733.

Shafai, S. A., Gohary, F. A., Nasr, F. A., Van Der Steen, N. P. \& Gijzen, H. J. 2007 Nutrient recovery from domestic wastewater using a UASB-duckweed ponds system. Bioresource Technology 98, 798-807.

Xu, J. \& Shen, G. 2oIr Growing duckweed in swine wastewater for nutrient recovery and biomass production. Bioresource Technology 102, 848-853.

Xu, J., Cui, W., Cheng, J. J. \& Stomp, A. M. 2or Production of highstarch duckweed and its conversion to bioethanol. Biosystems Engineering 110, 67-72. 
Copyright of Water Science \& Technology is the property of IWA Publishing and its content may not be copied or emailed to multiple sites or posted to a listserv without the copyright

holder's express written permission. However, users may print, download, or email articles for individual use. 